Article

\title{
Analysis and Implementation of a Phase-Shift Pulse-Width Modulation Converter with Auxiliary Winding Turns
}

\section{Bor-Ren Lin}

Department of Electrical Engineering, National Yunlin University of Science and Technology, Yunlin 640, Taiwan; linbr@yuntech.edu.tw; Tel.: +886-91-231-2281

Received: 9 December 2019; Accepted: 20 December 2019; Published: 2 January 2020

\begin{abstract}
A phase-shift pulse-width modulation converter is studied and investigated for railway vehicle or solar cell power converter applications with wide voltage operation. For railway vehicle applications, input voltage range of dc converters is requested to have $30-40 \%$ voltage variation of the nominal input voltage. The nominal input voltages of dc converters on railway vehicles applications may be $37.5 \mathrm{~V}, 48 \mathrm{~V}, 72 \mathrm{~V}, 96 \mathrm{~V}$ and $110 \mathrm{~V}$. Therefore, a new dc converter with wide input voltage operation from 25 to $150 \mathrm{~V}$ is presented to withstand different nominal input voltage levels such as $37.5-110 \mathrm{~V}$ on railway power units. To realize wide input voltage operation, an auxiliary switch and auxiliary transformer windings are used on output side of conventional full-bridge converter to have different voltage gains under different input voltage values. Phase-shift pulse-width modulation is adopted in the developed dc converter to accomplish soft switching operation on power switches. To confirm and validate the practicability of the presented converter, experiments based on a $300 \mathrm{~W}$ prototype were provided in this paper.
\end{abstract}

Keywords: PS-PWM (Phase-shift pulse-width modulation); power converter; full-bridge converter

\section{Introduction}

High efficiency power converters have been developed in renewable energy power conversion. However, the output voltage of solar panel varies widely and the voltage value is related to solar intensity. Thus, dc converters with wide voltage operation are demanded to convert solar energy to electric power. The dc-dc converters are required on railway vehicles for communication systems, braking systems, electric door systems and solid state lighting systems. However, the nominal input voltages of these control systems are different. The normal input voltages for the different applications are $110 \mathrm{~V}, 72 \mathrm{~V}, 48 \mathrm{~V}$ and $37.5 \mathrm{~V}$. The international standard EN50155 demands a minimum $\pm 30 \%$ voltage variation of the nominal input voltage for $\mathrm{dc}$-dc converters in railway applications. Therefore, high efficiency dc-dc converters with wide input voltage operation from $37.5 \mathrm{~V}$ to $110 \mathrm{~V}$ with $\pm 30 \%$ voltage variation are necessary for railway systems. Two-stage converters [1-3] are normally employed to realize wide voltage operation. The buck, buck-boost or boost circuit topology can be used in the first stage and full-bridge, half-bridge, forward or flyback circuit topology can be used in the second stage. However, the drawbacks of two stage converters are low circuit efficiency and more circuit components. The dc converters with series/parallel connection to achieve wide input voltage operation have been presented in [4-7]. Full-bridge or half-bridge converters with phase-shift pulse-width modulation (PS-PWM) on the secondary side have been discussed in [8-11] to realize soft switching and wide voltage operation. Series resonant converters or PS-PWM converters with wide voltage operation have been proposed in [12-19]. However, the input or output voltage range proposed in circuit topologies [4-19] is less than 4:1, i.e. $V_{i n, \max } \leq 4 V_{i n, \min }$. For solar power conversion or 
railway vehicle power converters, the input voltage range of dc converters may be greater than $6: 1$, i.e. $V_{i n, \max } \geq 6 V_{\text {in, } \min }$.

A single-stage dc converter is investigated to accomplish the wider voltage range (6:1 input voltage range, 150-25 V) and less switching loss. Full-bridge converter with two secondary windings and an auxiliary switch is used to achieve wide voltage range operation capability. For the low input voltage range, the auxiliary switch on output side is conducting. Thus, the high turns-ratio between the secondary-side and primary-side of transformer is employed to generate high voltage gain. On the other hand, the auxiliary switching is off and low transformer turns-ratio is adopted to obtain low voltage gain under high input voltage operation. Therefore, the wide voltage range operation is achieved in the presented circuit. Since the PS-PWM scheme is used to control full-bridge converter, active devices on the studied converter are worked at zero-voltage switching so that the switching losses can be decreased. Compared to conventional two-stage dc converters, the proposed converter has less power conversion stage and better circuit efficiency. Compared to conventional single-stage dc converters with 2:1 or 4:1 voltage range, the proposed converter has much wider input voltage operation range with 6:1 voltage range. Finally, the performance of the developed circuit is investigated by the measured waveforms from a laboratory circuit.

\section{Circuit Structure}

The proposed circuit with wide voltage operation is shown in Figure 1a. The basic structure of the studied circuit is a full-bridge circuit, $Q_{1} \sim Q_{4}, L_{l k}$, and $T$, on input side and a center-tapped rectifier with two sets of secondary windings $N_{s 1}$ and $N_{s 2}$ and an auxiliary switch $S$ on output side.

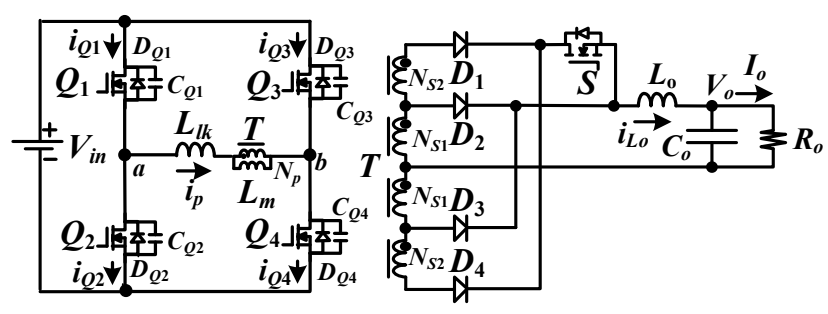

(a)

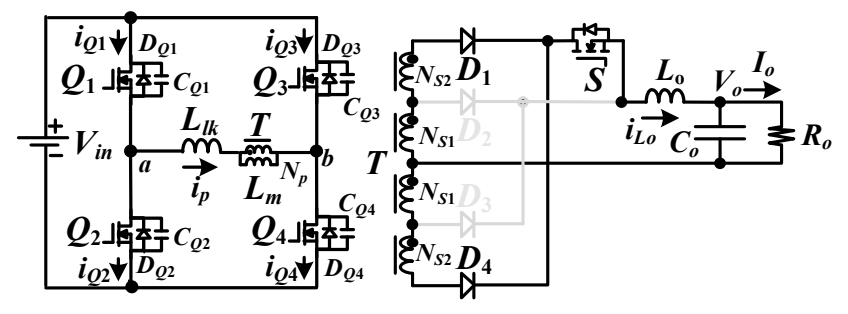

(b)

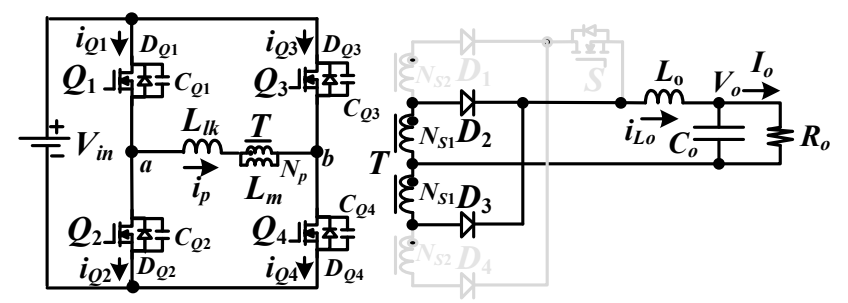

(c)

Figure 1. Proposed 6:1 wide voltage range converter (a) circuit diagram (b) low voltage range operation (c) high voltage range operation. 
In relation to input voltage value, the studied circuit has two voltage operation ranges, low input voltage range and high input voltage range. When $V_{\text {in }}$ is at low voltage range $V_{\text {in }}=V_{\text {in, } \text {, in }} \sim 3 V_{\text {in,min }}$ (3:1 operation range), the auxiliary switch $S$ is in the on-state (Figure 1b). $D_{2}$ and $D_{3}$ are reverse biased. The secondary winding turns $N_{s 1}+N_{s 2}$ are connected to output side. The turn-ratio of transformer $T$ is $N_{p} /\left(N_{s 1}+N_{s 2}\right)$ and the converter has higher dc voltage gain for low input voltage operation. The effective duty cycle of full-bridge converter is depended on input voltage value to maintain output voltage constant. PS-PWM scheme is used to control phase-shift angle between the lagging-leg and leading-leg. Therefore, the soft switching characteristics of power switches on full-bridge converter can be achieved. If $V_{\text {in }}$ is at high voltage range $V_{\text {in }}=2 V_{\text {in, } \min } \sim 6 V_{i n, \min }$ (3:1 operation range), auxiliary switch $S$ is in the off-state and $D_{1}$ and $D_{4}$ are off as shown in Figure $1 c$. The secondary turns $N_{s 1}$ are connected to output side and the transformer turn-ratio is $N_{p} / N_{s 1}$. Thus, the presented circuit has lower dc voltage gain in high input voltage operation. Based on the on/off states of auxiliary switch $S$ and winding turns $N_{s 1}+N_{s 2}$ or $N_{s 1}$ connected to output load, a soft switching full-bridge converter with 6:1 $\left(V_{i n, \max } / V_{i n, \min }=6\right)$ wide input voltage range is accomplished in the studied circuit.

\section{Operation Principle}

The duty cycle control is used to generate the proper switching signals and provide a stable output voltage against the variation of $V_{i n}$ and $I_{0}$. According to input voltage value, auxiliary switch $S$ is controlled at on-state or off-state for low voltage range operation or high voltage range operation. In the studied converter, it is assumed that $L_{m}>>L_{l k}, C_{Q 1}=\ldots=C_{Q 4}=C_{o s s}$ and $N_{s 1}=N_{s 2}=N_{s}$. The proposed circuit has two input voltage ranges, $V_{i n, \min } \sim 3 V_{i n, \min }$ and $2 V_{i n, \min } \sim 6 V_{i n, \min }$. The pulse-width modulation waveforms and the equivalent circuits for two input voltage ranges are provided in Figures 2 and 3. For each input voltage range, the proposed circuit has ten modes in every switching cycle.

\subsection{Low Voltage Range (S on)}

When $V_{\text {in,min }}<V_{\text {in }}<3 V_{\text {in,min }}$, auxiliary switch $S$ is turned on. The effective duty cycle $d_{\text {eff }}$ of full-bridge circuit is related to input voltage. The transformer turn-ratio in low voltage range is $n_{L}=N_{p} /\left(N_{s 1}+N_{s 2}\right)$. The dc voltage gain is expressed as $G_{L}=V_{o} / V_{i n . L}=2 d_{\text {eff }} / n_{L}$ where $V_{i n, L}$ denotes $V_{\text {in }}$ in low input voltage range. The pulse-width modulation waveforms are given in Figure 2a and the ten equivalent circuits for low voltage range operation are provided in Figure $2 \mathrm{~b}-\mathrm{k}$.

Mode $1\left[t_{0}, t_{1}\right]$ : In mode $1, Q_{1}$ and $Q_{4}$ are on and $v_{L m} \approx V_{\text {in }}$ due to $L_{m}>L_{l k}$ The power flow from input source to output load is through $L_{l k}, T, D_{1}, L_{o}$ and $C_{o}$. The output inductor voltage $v_{L o} \approx V_{i n} / n_{L}-$ $V_{o}>0$ and $i_{L o}$ increases.

Mode $2\left[t_{1}, t_{2}\right]: Q_{1}$ is off at time $t_{1}$. Because of $i_{p}\left(t_{1}\right)>0, C_{Q 2}\left(C_{Q 1}\right)$ is discharged (charged). Due to $C_{Q 1}$ and $C_{Q 2}$ are low capacitances, $i_{p}$ and $i_{D 1}$ are almost constant. At time $t_{2}, v_{C Q 2}=0$ and the time duration in mode 2 is calculated as $\Delta t_{\text {mode } 2} \approx 2 V_{\text {in }} C_{\text {oss }} n_{L} / i_{\text {Lo }}\left(t_{1}\right)$.

Mode $3\left[t_{2}, t_{3}\right]$ : Since $i_{p}\left(t_{2}\right)>0$ and $v_{\mathrm{CQ}_{2}}\left(t_{2}\right)=0, D_{\mathrm{Q} 2}$ conducts and $Q_{2}$ turns on after $t_{2}$ to have zero-voltage switching characteristic. In order to have soft switching operation, the dead time $t_{d}$ between $Q_{1}$ and $Q_{2}$ is needed and expressed as $t_{d}>\Delta t_{\text {mode } 2}=2 V_{\text {in }} C_{\text {oss }} n_{L} / i_{L o}\left(t_{1}\right)$. Since $L_{l k}<<L_{m}$ and $R_{o n, s w}$ (turn-on resistance of switches $Q_{1}$ and $Q_{2}$ ) is about hundreds of milliohm, the transformer primary voltage $v_{L m}$ and the secondary voltages $v_{s, N 1}$ and $v_{s, N 2}$ approximate zero voltage. $D_{1}$ and $D_{4}$ are forward biased. Then the inductor voltage $v_{L o}=-V_{o}$ and $i_{L o}$ decreases. The primary current $i_{P}(t) \approx i_{P}\left(t_{2}\right)-V_{\mathrm{Q} 24, d r o p} / r_{l k}$ where $r_{l k}$ is the equivalent resistance on $L_{l k}$ and $V_{\mathrm{Q} 24, \text { drop }}$ is voltage drop on $Q_{2}$ and $Q_{4}$.

Mode $4\left[t_{3}, t_{4}\right]$ : At time $t_{3}, S_{4}$ is off. Because of $i_{p}\left(t_{3}\right)>0, C_{S 3}\left(C_{S 4}\right)$ is discharged (charged). Due to $C_{S 3}$ and $C_{S 4}$ are low capacitances, $i_{p}, i_{D 1}$ and $i_{D 4}$ are constant. At time $t_{4}, v_{C Q 3}=0$. The time duration in mode 4 is calculated as $\Delta t_{\text {mode }} 4 \approx 2 V_{\text {in }} C_{\text {oss }} / i_{p}\left(t_{3}\right)$.

Mode $5\left[t_{4}, t_{5}\right]$ : Because of $i_{p}\left(t_{4}\right)>0$ and $v_{\mathrm{CQ} 3}\left(t_{4}\right)=0, D_{\mathrm{Q} 3}$ is forward biased and $S_{3}$ turns on after $t_{4}$ to have zero-voltage switching operation. Due to both $D_{1}$ and $D_{4}$ are conducting, the primary 
magnetizing voltage $v_{L m}$ is clamped at zero voltage. Thus, the leakage inductor voltage $v_{L l k}=-V_{\text {in }}$ and $i_{p}$ is decreased. In this mode, $i_{D 1}\left(i_{D 4}\right)$ is decreased (increased) to $0\left(i_{L o}\right)$ at time $t_{5}$. The time duration in mode 5 is expressed as:

$$
\Delta t_{\text {mode } 5}=\left(i_{p}\left(t_{4}\right)-i_{p}\left(t_{5}\right)\right) L_{l k} / V_{\text {in }} \approx 2 I_{o} L_{l k} /\left(n_{L} V_{\text {in }}\right)
$$

The duty loss in Mode 5 is calculated in (2):

$$
d_{l o s s, 5} \approx 2 I_{o} L_{l k} f_{s w} /\left(n_{L} V_{i n}\right)
$$

The waveforms in modes 6-10 are symmetry to waveforms in modes $1-5$. Therefore, the analysis and discussion of modes 6-10 are neglected in this section.

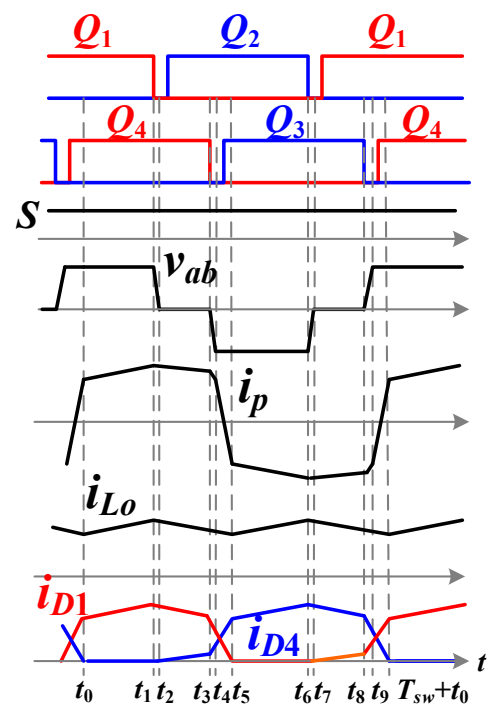

(a)
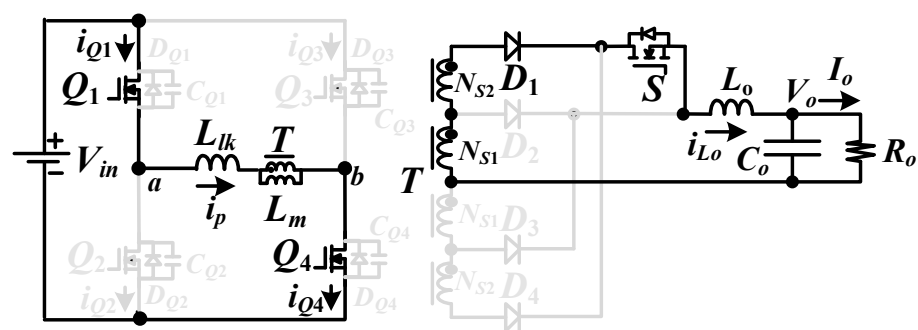

(b)
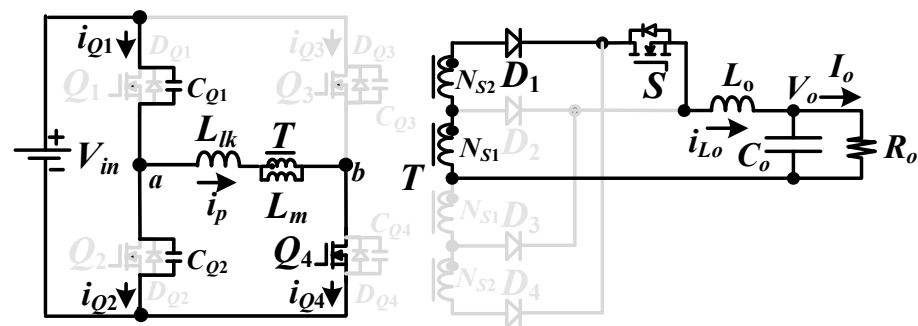

(c)

Figure 2. Cont. 


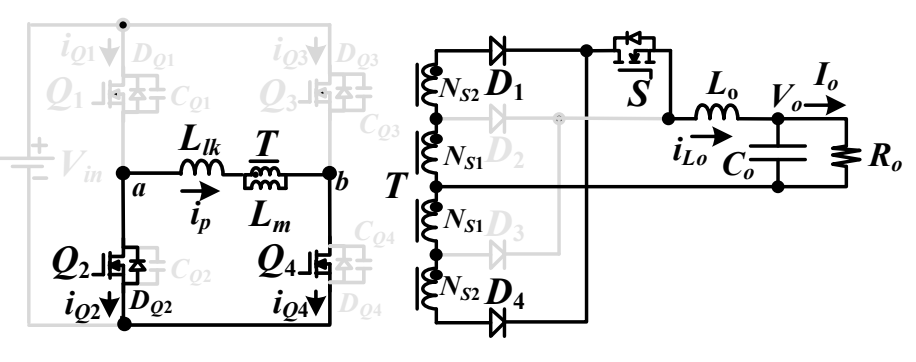

(d)

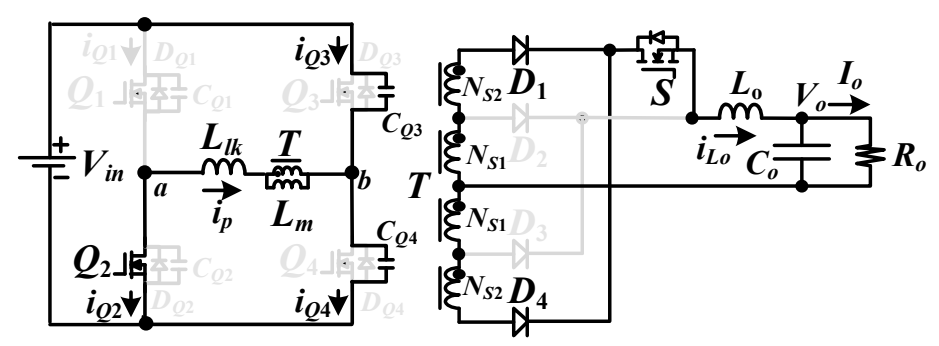

(e)

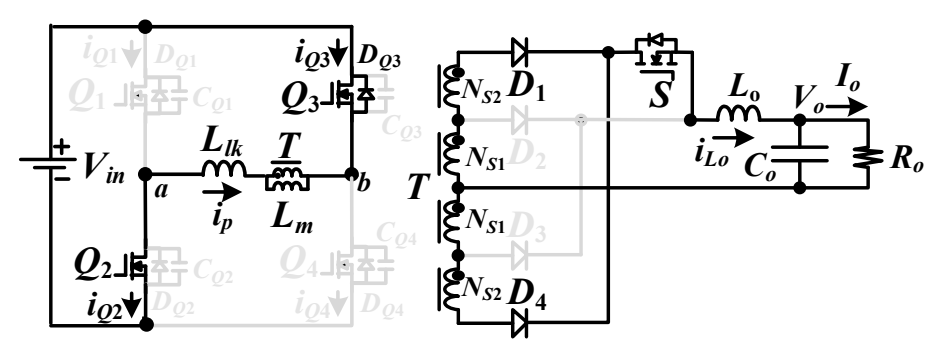

(f)

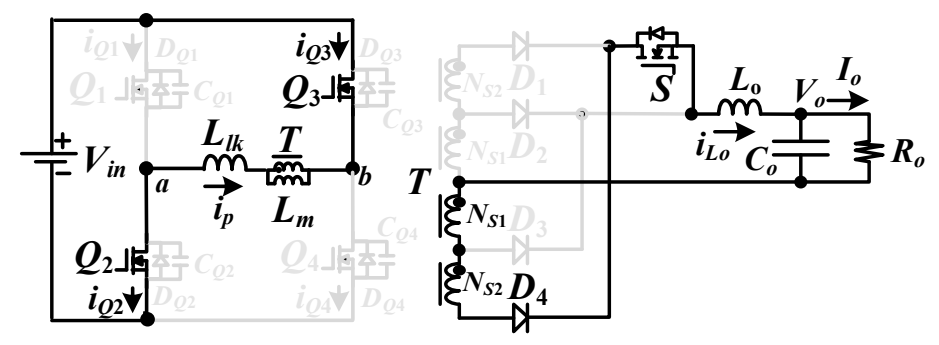

(g)
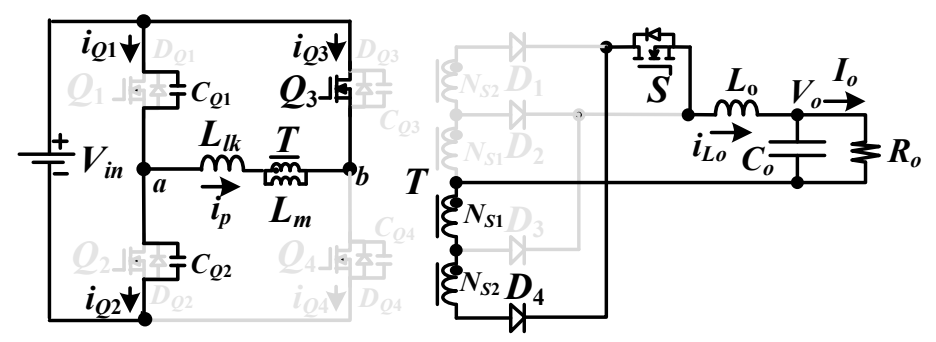

(h)

Figure 2. Cont. 


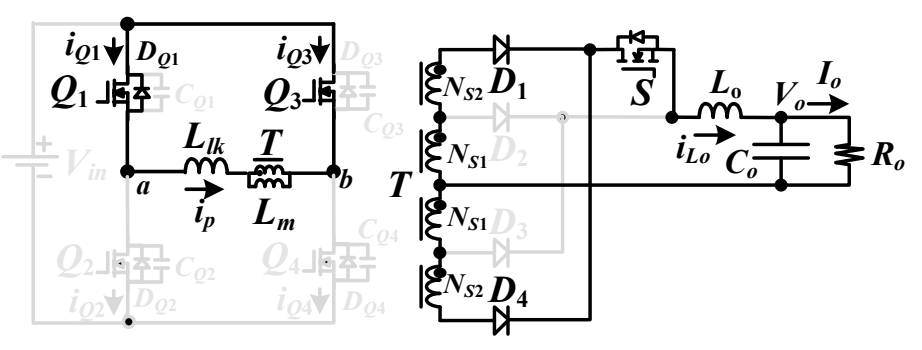

(i)

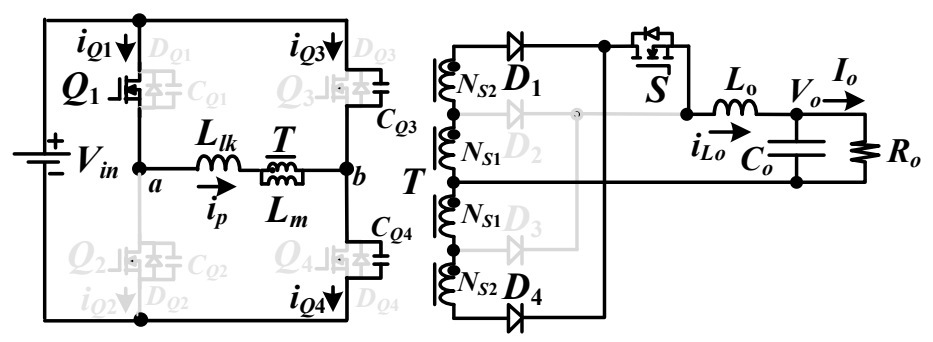

(j)
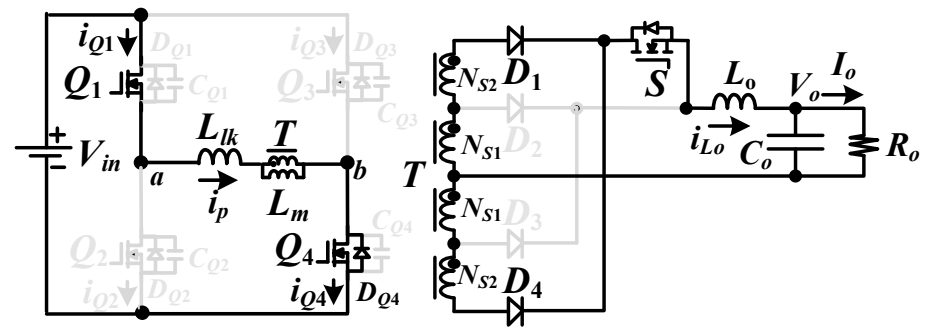

(k)

Figure 2. Proposed converter for low input voltage range (a) pulse-width modulation waveforms (b) mode 1 circuit (c) mode 2 circuit (d) mode 3 circuit (e) mode 4 circuit (f) mode 5 circuit (g) mode 6 circuit (h) mode 7 circuit (i) mode 8 circuit (j) mode 9 circuit (k) mode 10 circuit.

\subsection{High Voltage Range (S off)}

When $2 V_{\text {in, } \min }<V_{\text {in }} \leq 6 V_{\text {in,min }}, S$ is off and $D_{1}$ and $D_{4}$ are reverse biased as shown in Figure 1c. Only the secondary turns $N_{s 1}$ are connected to output load and the turn-ratio of transformer in high voltage range is $n_{H}=N_{p} / N_{s 1}$. The effective duty cycle $d_{\text {eff }}$ depends on $V_{\text {in }}$ and $I_{0}$. The dc voltage gain in high voltage range operation is given as $G_{H}=V_{o} / V_{i n, H}=2 d_{\text {eff }} n_{H}$ where $V_{i n, H}$ denotes $V_{\text {in }}$ in high input voltage range. Since turn-ratio $n_{H}=2 n_{L}$ due to $N_{s 1}=N_{s 2}$, it can obtain $G_{H}=G_{L} / 2$ under the same effective duty cycle $d_{\text {eff }}$. That means the proposed converter has high voltage gain in low input voltage range and low voltage gain in high input voltage range. The circuit waveforms in high voltage range operation are provided in Figure $3 a$ and the ten equivalent circuits for high voltage range operation are illustrated in Figure $3 b-k$. The circuit operation in Figure $3 b-k$ with the secondary winding turns $N_{s 1}$ in high voltage range are similar to the circuit operations in low voltage range presented in previous section. Therefore, the circuit analysis of the presented circuit operated at high voltage range are ignored in this section. 


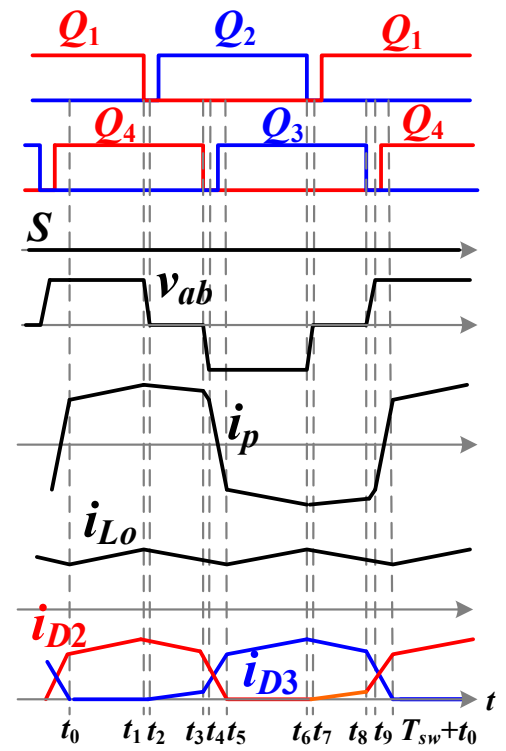

(a)

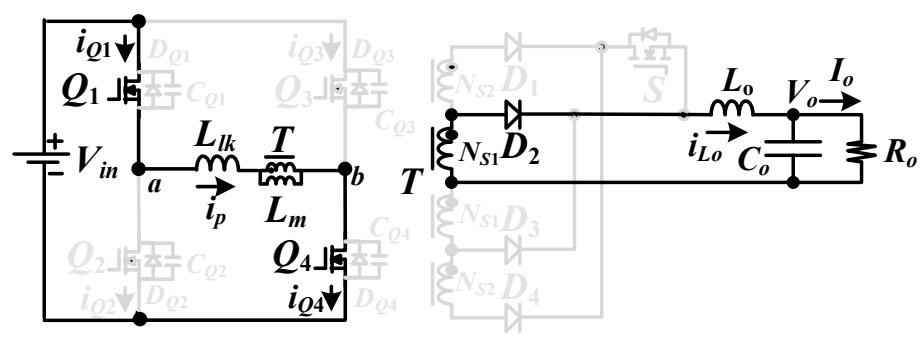

(b)

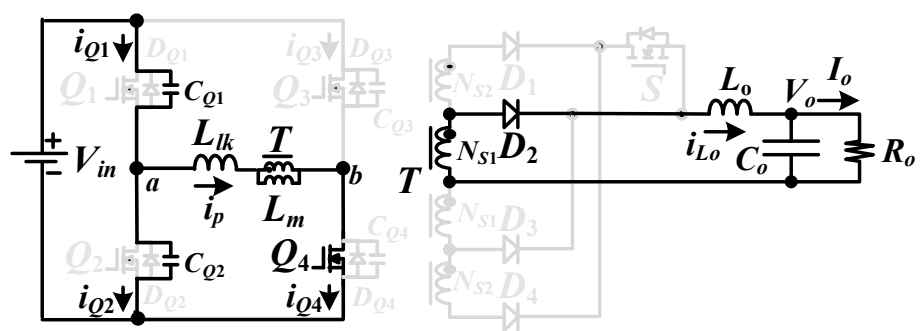

(c)

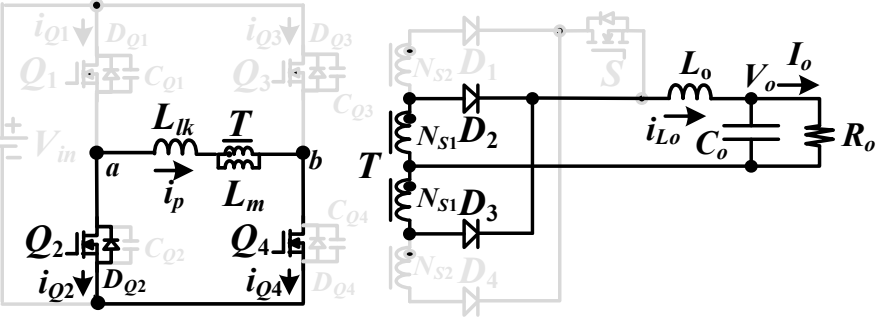

(d)

Figure 3. Cont. 


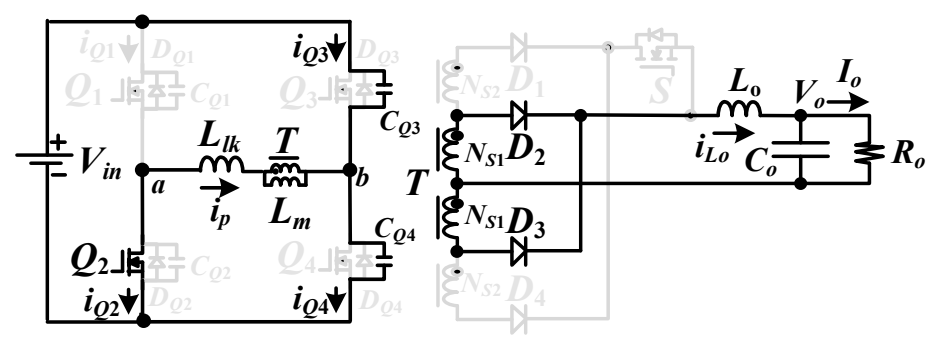

(e)

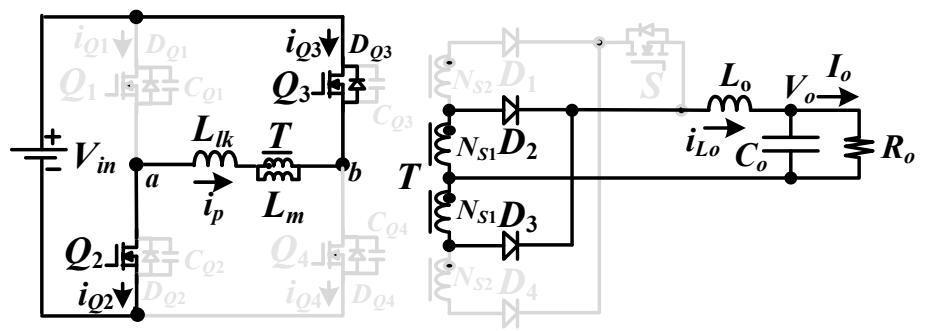

(f)

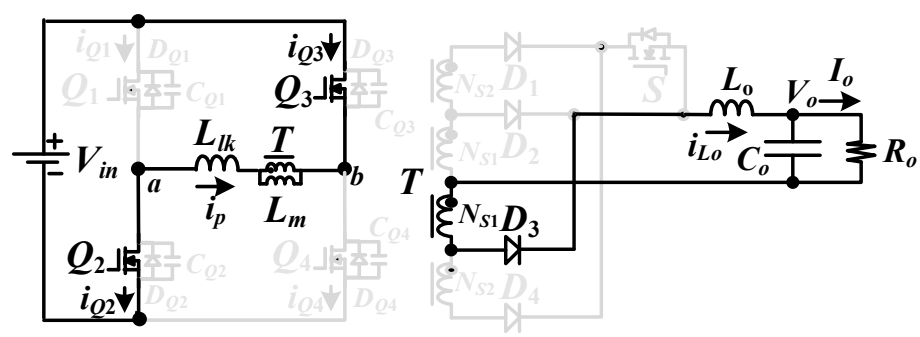

(g)
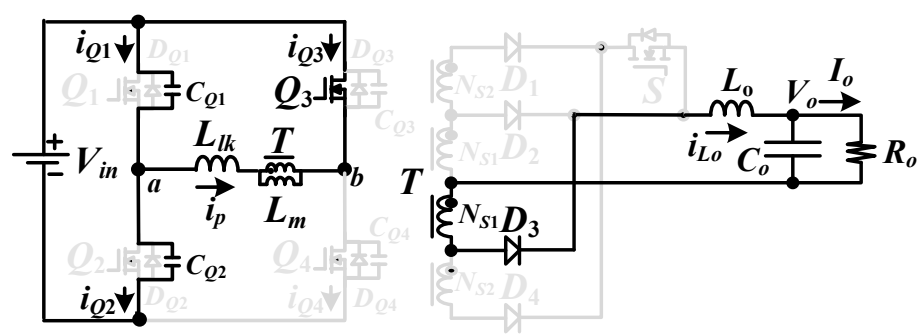

(h)

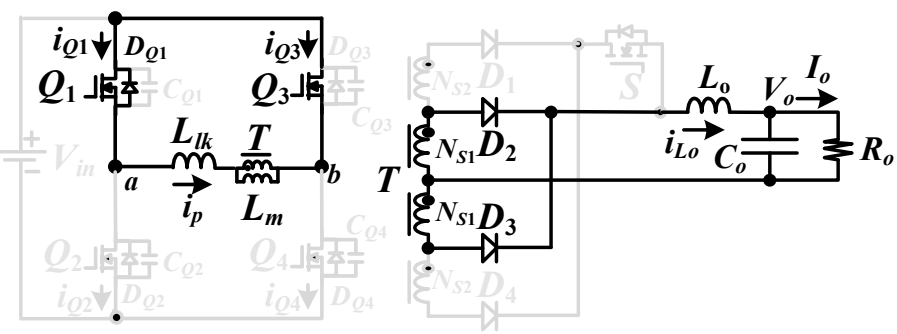

(i)

Figure 3. Cont. 


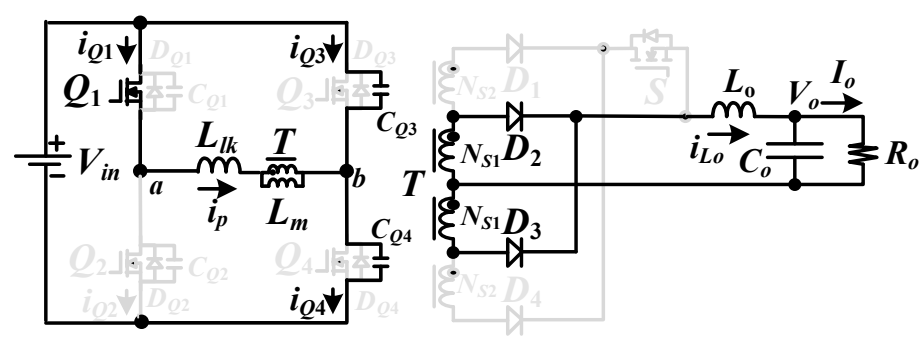

$(\mathbf{j})$
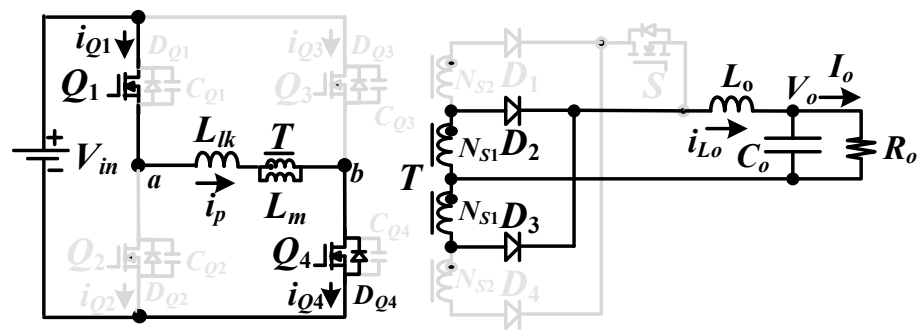

$(\mathbf{k})$

Figure 3. Proposed converter for high input voltage range (a) pulse-width modulation waveforms (b) mode 1 circuit (c) mode 2 circuit (d) mode 3 circuit (e) mode 4 circuit (f) mode 5 circuit (g) mode 6 circuit (h) mode 7 circuit (i) mode 8 circuit (j) mode 9 circuit (k) mode 10 circuit.

\section{Circuit Characteristics and Design Example}

Full-bridge PS-PWM converter with auxiliary secondary turns is adopted in the studied circuit to accomplish wide input voltage range operation. The effective duty cycle between the lagging-leg and leading leg is regulated under the different input voltage value and load current. For low (high) input voltage range, switch $S$ is on (off) and the winding turns $N_{s 1}+N_{s 2}\left(N_{s 1}\right)$ are connected to output terminal. The output voltage can be derived in (3) from flux balance theory on $L_{0}$ :

$$
V_{o}=\left\{\begin{array}{l}
\frac{2 V_{i n, L}}{n_{L}}\left(d-\frac{2 L_{l k} I_{o} f_{s w}}{n_{L} V_{i n, L}}\right), S \text { on } \\
\frac{2 V_{i n, H}}{n_{H}}\left(d-\frac{2 L_{l k} I_{o} f_{s w}}{n_{H} V_{i n, H}}\right), S \text { off }
\end{array}\right.
$$

where $d$ is duty cycle of leg voltage $v_{a b}$ and $d=d_{\text {eff }}-d_{\text {loss }, 5}$. The average value of output inductor current $i_{L o}$ equals $I_{o}$. The voltage ratings of active switches $Q_{1}-Q_{4}$ equal $V_{i n, \max }$. The voltage ratings of $D_{1}-D_{4}$ and $S$ are functions of $V_{\text {in, } \max }, n_{L}$ and $n_{H}$.

$$
\begin{gathered}
V_{D 1, \text { rating }}=V_{D 4, \text { rating }} \approx 2 V_{i n, \max } / n_{L} \\
V_{D 2, \text { rating }}=V_{D 3, \text { rating }} \approx 2 V_{i n, \max } / n_{H} \\
V_{S, \text { rating }} \approx V_{i n, \max } / n_{H}
\end{gathered}
$$

The average values of diode currents are $I_{D 1}=\ldots=I_{D 4}=I_{0} / 2$ and $I_{S, a v}=I_{o}$. The output inductance $L_{o}$ approximates:

$$
L_{o} \approx \frac{\left(V_{i n, \max } / n_{H}-V_{o}\right) d_{e f f, \min }}{\Delta i_{L o} f_{s w}}
$$

The duty loss in Mode 5 is related to the leakage inductance $L_{l k}$. If the maximum duty loss is defined, then the leakage inductance $L_{l k}$ is calculated in (8):

$$
L_{l k}=\frac{n_{L} d_{l o s s, 5} V_{i n, \min }}{2 I_{o} f_{s w}}
$$


The proposed converter is designed with the following parameters: $V_{\text {in }}=150-25 \mathrm{~V}$ (6:1 ratio), $V_{o}=12 \mathrm{~V}, I_{0, \text { rated }}=25 \mathrm{~A}, P_{o}=300 \mathrm{~W}$ and $f_{s w}=100 \mathrm{kHz}$. When $V_{\text {in }}=25-75 \mathrm{~V}$ (low input voltage range), auxiliary switch $S$ is on to obtain a high voltage gain due to the secondary turns $N_{s 1}+N_{s 2}$ are connected to output side. If $V_{\text {in }}$ is increased and equal to $75 \mathrm{~V}$, then switch $S$ turns off and the converter is operated in high voltage range. The winding turns $N_{s 1}$ are connected to output side. If the input voltage is decreased from $150 \mathrm{~V}$ to $50 \mathrm{~V}$, then switch $S$ turns on and the circuit is operated in low voltage range. Thus, the proposed converter works in high voltage range when $V_{\text {in }}=150-50 \mathrm{~V}$. It is assumed the proposed converter has $85 \%$ efficiency at $V_{\text {in, } \min }=25 \mathrm{~V}$ and $100 \%$ power under low voltage range. The maximum duty cycle of leg voltage $v_{a b}$ at $V_{i n, \min }=25 \mathrm{~V}$ is assumed 0.45 and the assumed duty cycle loss $d_{\text {loss }, 5}=0.08$ :

$$
d_{l o s s, 5}=2 I_{0} L_{l k} f_{s w} / n_{L} V_{i n, \min }=0.04
$$

From (3) and (9), the leakage inductance approximates:

$$
L_{l k}=\frac{\eta d_{l o s s, 5} d_{\max } V_{i n, \min }^{2}}{P_{o} f_{s w}} \approx 0.6375 \mu \mathrm{H}
$$

From (3), the turn-ratio $n_{L}$ can be derived in (11):

$$
n_{L} \approx \frac{d_{\max } V_{i n, \min }+\sqrt{\left(d_{\max } V_{i n, \min }\right)^{2}-4 V_{o} L_{l k} I_{o} f_{s w}}}{V_{o}} \approx 1.5
$$

In the prototype circuit, transformer $T$ is implemented using TDK (Tokyo Electric Chemical Industry Co., Ltd.) EER-42 ferrite core with winding turns $N_{p}=12$ and $N_{s 1}=N_{s 1}=4$ and $L_{m}=400 \mu \mathrm{H}$. The minimum effective duty cycle $d_{\text {eff, } \text {, } i n}$ at $V_{\text {in,L,max }}=75 \mathrm{~V}$ is derived in (12):

$$
d_{e f f, \text { min }}=\frac{d_{e f f, \max } V_{i n, L, \min }}{V_{i n, L, \max }}=\frac{(0.45-0.08) \times 25}{75} \approx 0.123
$$

The maximum ripple current $\Delta i_{L o}$ at $V_{i n, L, \max }=75 \mathrm{~V}$ (low input voltage range) is assumed $30 \%$ of load current. From (7), the inductance $L_{o}$ is expressed as:

$$
L_{o} \approx \frac{\left(V_{i n, L, \max } / n_{L}-V_{o}\right) d_{e f f, \min }}{\Delta i_{L o} f_{s w}} \approx 6.23 \mu \mathrm{H}
$$

The $L_{o}=8 \mu \mathrm{H}$ is used in the prototype circuit. The rms (root-mean-square) currents of $Q_{1}-Q_{4}$ are approximately calculated as:

$$
i_{Q 1, r m s}=\ldots=i_{Q 4, r m s}=\frac{I_{o, r a t e d}}{n_{L} \eta \sqrt{2}} \approx 13.9 \mathrm{~A}
$$

The maximum voltage on $Q_{1}-Q_{4}$ is the maximum input voltage $V_{\text {in,max }}=150 \mathrm{~V}$. The average diode currents $I_{D 1}-I_{D 4}$ are $12.5 \mathrm{~A}$. The voltage ratings of $D_{1}-D_{4}$ are given in (15) and (16):

$$
\begin{aligned}
& V_{D 1, \text { rating }}=V_{D 4, \text { rating }} \approx 2 V_{i n, \max } / n_{L}=200 \mathrm{~V} \\
& V_{D 2, \text { rating }}=V_{D 3, \text { rating }} \approx 2 V_{i n, \max } / n_{H}=100 \mathrm{~V}
\end{aligned}
$$

MOSFETs (metal-oxide-semiconductor field-effect transistor) IRFB4229 with $250 \mathrm{~V} / 46$ A ratings are adopted for active switch $Q_{1} \sim Q_{4}$ and IRF3145 with $150 \mathrm{~V} / 30 \mathrm{~A}$ ratings is adopted for auxiliary switch $S$. Fast recovery diodes APT30DQ60BG with $600 \mathrm{~V} / 30 \mathrm{~A}$ ratings are selected for $D_{1}-D_{4}$ and the output capacitance $C_{o}=2000 \mu \mathrm{F}$. 


\section{Simulated and Experimental Results}

Figure 4a shows the control block of the signals $Q_{1} \sim Q_{4}$ and $S$. Schmitt trigger comparator is adopted to generate the signal $S$ in order to select the correct range of input voltage. The PWM signals are generated by phase-shift PWM integrated circuit UCC3895. The output voltage is controlled by the voltage regulator TL431 and PC817. Figure $4 \mathrm{~b}$ provides the photograph of the prototype. Figure 5 demonstrates the simulated results of the primary-side and the secondary-side voltages and currents at full load under low input voltage range for both $V_{i n}=25 \mathrm{~V}$ and $75 \mathrm{~V}$. One can observe that the effective duty cycle of $v_{a b}$ at $V_{\text {in }}=25 \mathrm{~V}$ is larger than the duty cycle at $V_{i n}=75 \mathrm{~V}$. Therefore, the current ripple $\Delta i_{L o}$ at $V_{i n}=25 \mathrm{~V}$ is less than current ripple $\Delta i_{L o}$ at $V_{i n}=75 \mathrm{~V}$. Similarly, the simulated results of the presented circuit operated at high input voltage range are provided in Figure 6 for both $V_{\text {in }}=150 \mathrm{~V}$ and $50 \mathrm{~V}$. The lower input voltage $\left(V_{i n}=50 \mathrm{~V}\right)$ has the larger duty cycle to reduce the output ripple current $\Delta i_{\text {Lo }}$ compared to the condition at $V_{\text {in }}=150 \mathrm{~V}$ case. Experiments from a prototype with circuit components derived from previous section are provides to demonstrate the converter performance. The proposed circuit is operated at low input voltage range when $V_{\text {in }}$ is increased from $25 \mathrm{~V}$ to $75 \mathrm{~V}$. Then, the circuit goes to the high input voltage mode. If the input voltage is decreased from $150 \mathrm{~V}$ to $50 \mathrm{~V}$, then the circuit operation goes to low input voltage range. Based on the input voltage operation range. Figures 7-9 gives the test results when input voltage is in low voltage range. Under low input voltage range, auxiliary switch $S$ is on. Thus, the rectifier diodes $D_{2}$ and $D_{3}$ are reverse biased and off. Figure $7 \mathrm{a}, \mathrm{b}$ show the experimental waveforms of the gate voltages, leg voltage $v_{a b}$ and the primary current $i_{p}$ at $V_{i n}=25 \mathrm{~V}$ and $75 \mathrm{~V}$ and the rated output. It is clear that the converter has less phase-shift between $Q_{1}$ and $Q_{4}$ and larger duty cycle on leg voltage $v_{a b}$ at $V_{\text {in }}=25 \mathrm{~V}$ input. Figure $7 \mathrm{c}$, d provides the test waveforms of $i_{D 1}, i_{D 4}$ and $i_{L o}$ at $V_{i n}=25 \mathrm{~V}$ and $75 \mathrm{~V}$ and the rated power. Due the converter at $V_{\text {in }}=25 \mathrm{~V}$ input has large duty cycle, $i_{\text {Lo }}$ has less current ripple at $V_{i n}=25 \mathrm{~V}$ input compared to $V_{\text {in }}=75 \mathrm{~V}$ input. Figure $8 \mathrm{a}, \mathrm{b}$ provides the experimental waveforms of switch $Q_{1}$ in leading-leg at $20 \%$ and $100 \%$ loads under $V_{\text {in }}=25 \mathrm{~V}$ input. It is clear the soft switching operation of $Q_{1}$ is achieved from $20 \%$ load under $25 \mathrm{~V}$ input case. In the same manner, test waveforms of $Q_{1}$ at $20 \%$ and $100 \%$ loads under $75 \mathrm{~V}$ input are given in Figure 8c,d. It can observe that $Q_{1}$ is also turned on at zero-voltage switching from $20 \%$ load at $V_{\text {in }}=75 \mathrm{~V}$ input case. Switches $Q_{1}$ and $Q_{2}$ have the same turn-on/off characteristics in the leading-leg. Therefore, the soft switching operation of switches $Q_{1}$ and $Q_{2}$ at leading-leg can be accomplished from $20 \%$ load in low input voltage range operation. Figure $9 \mathrm{a}, \mathrm{b}$ show the test waveforms of the switch $Q_{3}$ at lagging-leg for $20 \%$ and $100 \%$ loads under $25 \mathrm{~V}$ input. It is clear that $Q_{3}$ is also turned on at zero voltage switching from $20 \%$ load. Figure $9 \mathrm{c}, \mathrm{d}$ provide the measured waveforms of $Q_{3}$ at $75 \mathrm{~V}$ input. It can observe that $Q_{3}$ is hard switching at $75 \mathrm{~V}$ input case for both $20 \%$ and $100 \%$ loads. The soft switching condition of power switches at lagging-leg (leading-leg) is related to the leakage inductor (output inductor). Normally, the leakage inductance is much less than the output inductance. Therefore, power switches at leading-leg have wide zero-voltage switching range compared to the lagging-leg switches. The test results shown in Figures 8 and 9 agree with these statements. Figures 10-12 gives the experimental waveforms of the proposed converter for high input voltage range operation at $150 \mathrm{~V}$ and $50 \mathrm{~V}$ input. The test waveforms of $v_{Q 1, g}, v_{Q 4, g}, v_{a b}$ and $i_{p}$ at $V_{\text {in }}=150 \mathrm{~V}$ and $50 \mathrm{~V}$ under rated power are provided in Figure 10a,b. Compared to $150 \mathrm{~V}$ input case, the proposed converter has less phase-shift between $Q_{1}$ and $Q_{4}$ and larger duty cycle on leg voltage $v_{a b}$ at $V_{\text {in }}=50 \mathrm{~V}$ input. The test results of $i_{D 1}, i_{D 4}$ and $i_{L o}$ at $100 \%$ load under $150 \mathrm{~V}$ and $50 \mathrm{~V}$ input are shown in Figure 10c,d. Figure 11 provides the experimental waveforms of leading-leg switch $Q_{1}$ at various load power and input voltage values in high voltage range operation. It is clear that the soft switching operation of $Q_{1}$ is accomplished from $20 \%$ load for both $150 \mathrm{~V}$ and $50 \mathrm{~V}$ input. Similarly, the test waveforms of lagging-leg switch $Q_{3}$ at various load power and input voltage values are demonstrated in Figure 12. It can be observed that $Q_{3}$ has soft switching operation only at $50 \mathrm{~V}$ input under $100 \%$ load and hard switching operation for the other conditions. Figure 13 provides the test results of the circuit efficiencies. For both low and high voltage range operation, the lower input voltage has larger effective duty cycle and less conduction losses on power switches compared 
to the higher input voltage. Thus, the circuit efficiency at $25 \mathrm{~V}$ input is better than $75 \mathrm{~V}$ input in low input voltage range. Similarly, the circuit efficiency at $50 \mathrm{~V}$ is better than $150 \mathrm{~V}$ input in high voltage range operation.

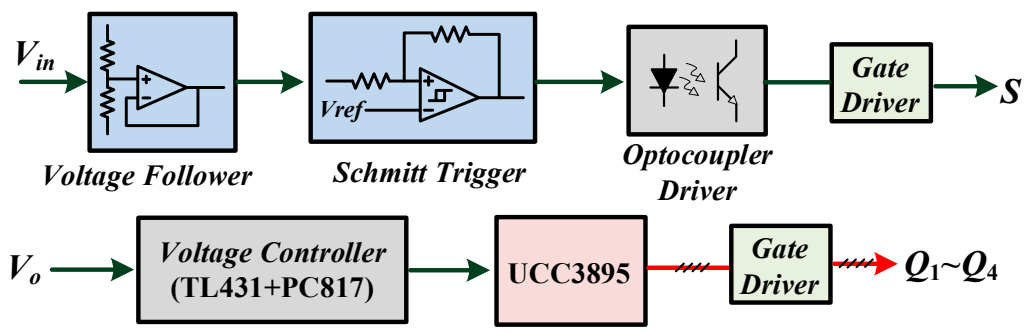

(a)

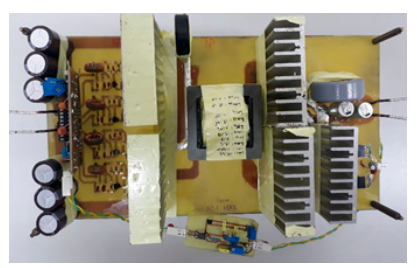

(b)

Figure 4. Prototype circuit (a) control block of the signals $S$ and $Q_{1} \sim Q_{4}$ (b) picture of the prototype.

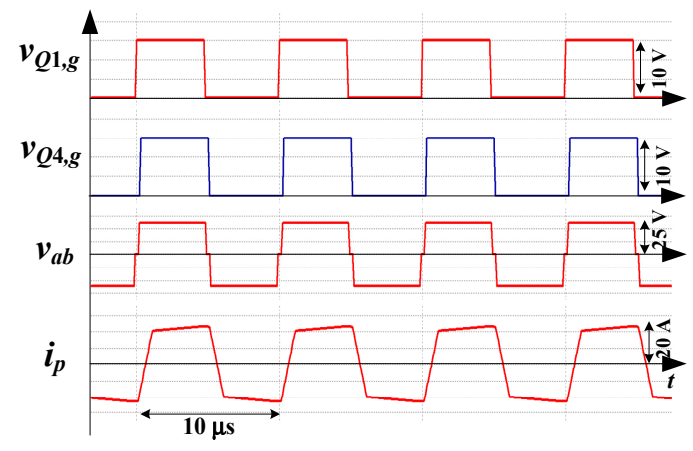

(a)

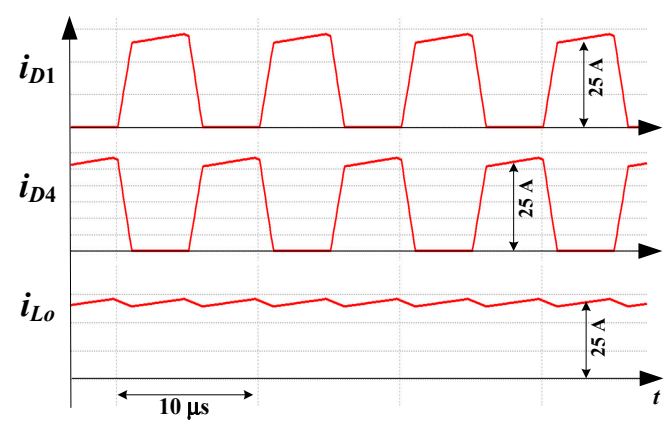

(c)

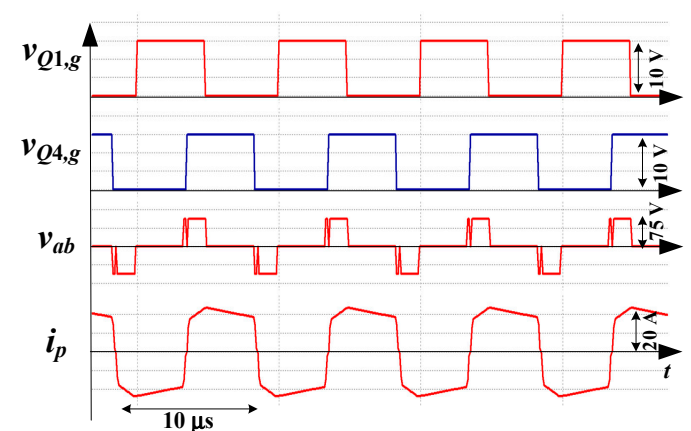

(b)

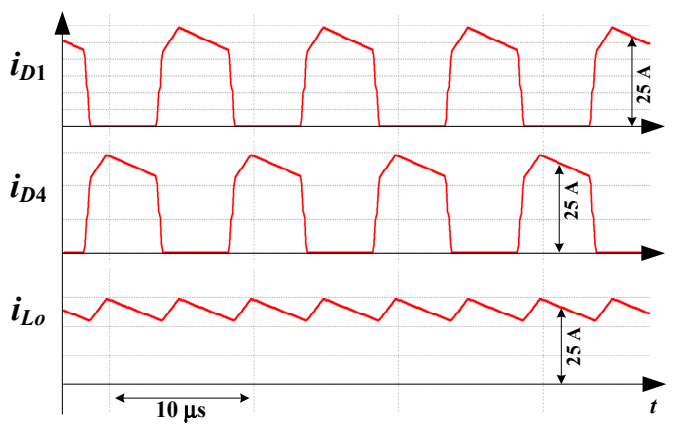

(d)

Figure 5. Simulated results in low input voltage range and full load (a) primary side waveforms at $25 \mathrm{~V}$ input (b) primary side waveforms at $75 \mathrm{~V}$ input (c) secondary side waveforms at $25 \mathrm{~V}$ input (d) secondary side waveforms at $75 \mathrm{~V}$ input. 


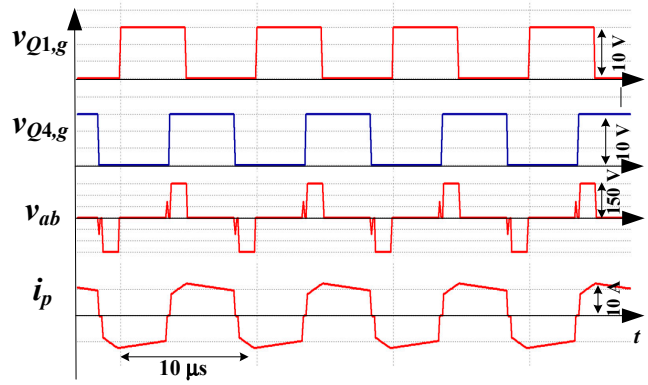

(a)

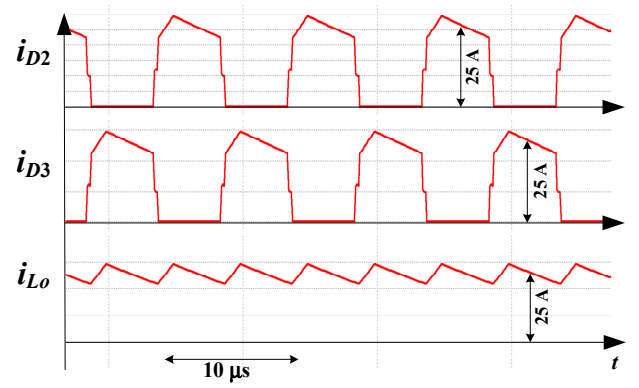

(c)

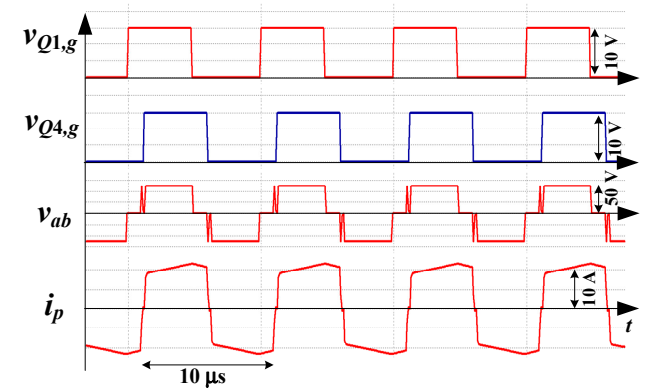

(b)

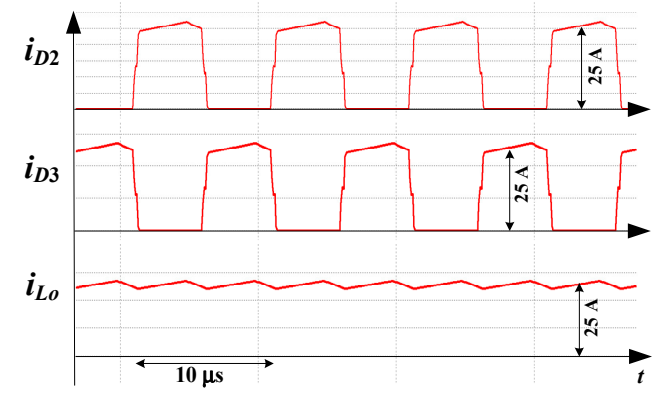

(d)

Figure 6. Simulated results in high input voltage range and full load (a) primary side waveforms at $150 \mathrm{~V}$ input (b) primary side waveforms at $50 \mathrm{~V}$ input (c) secondary side waveforms at $150 \mathrm{~V}$ input (d) secondary side waveforms at $50 \mathrm{~V}$ input.

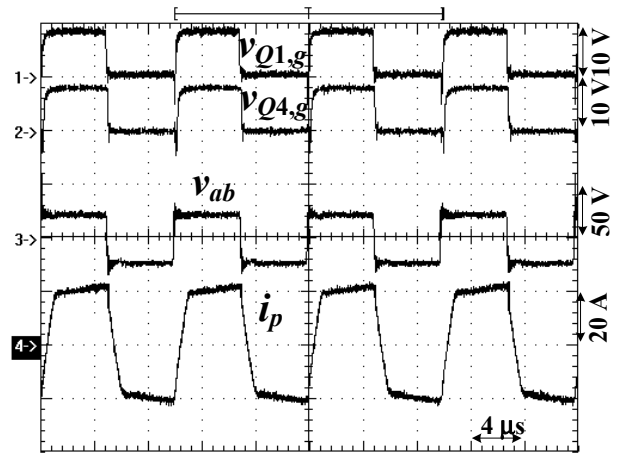

(a)

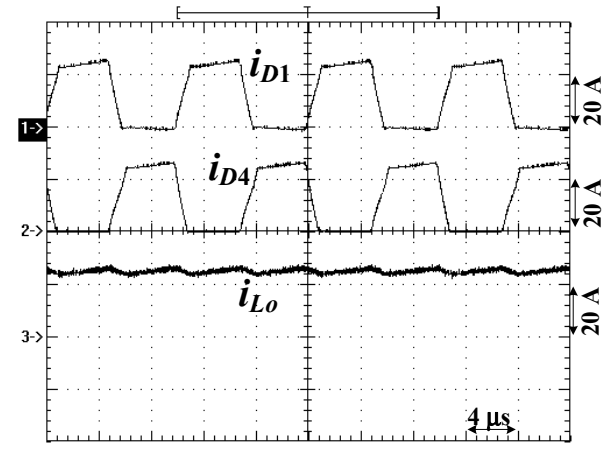

(c)

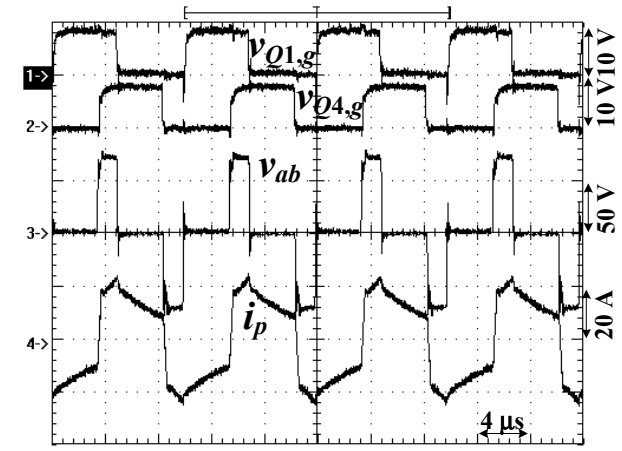

(b)

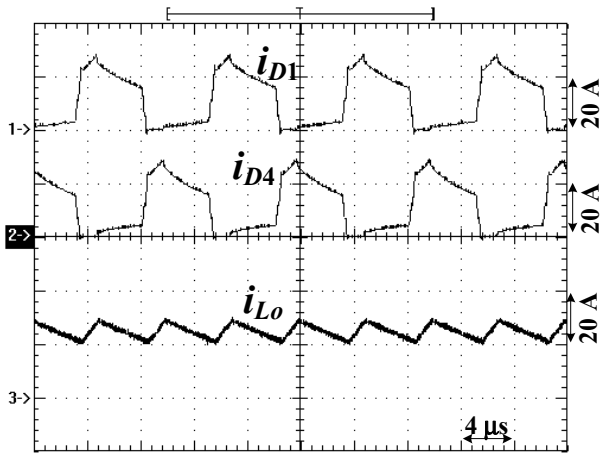

(d)

Figure 7. Experimental results in low input voltage range and full load (a) primary side waveforms at $25 \mathrm{~V}$ input (b) primary side waveforms at $75 \mathrm{~V}$ input (c) secondary side waveforms at $25 \mathrm{~V}$ input (d) secondary side waveforms at $75 \mathrm{~V}$ input. 


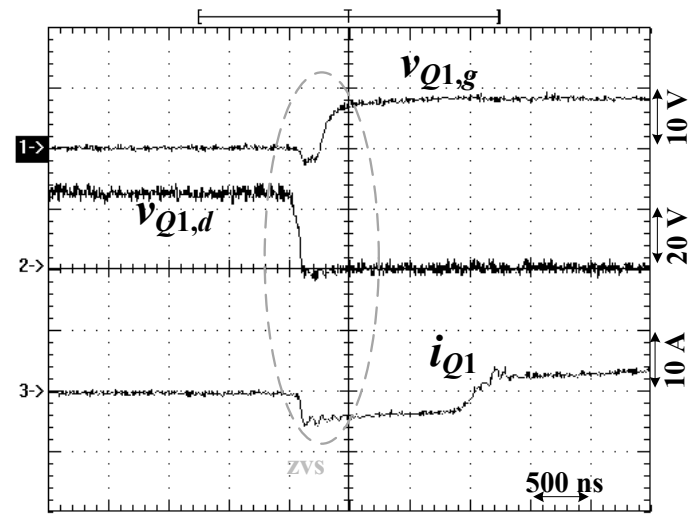

(a)

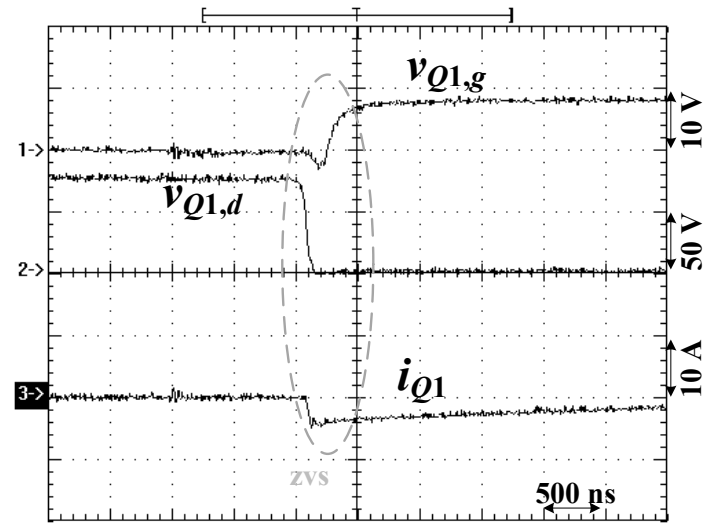

(c)

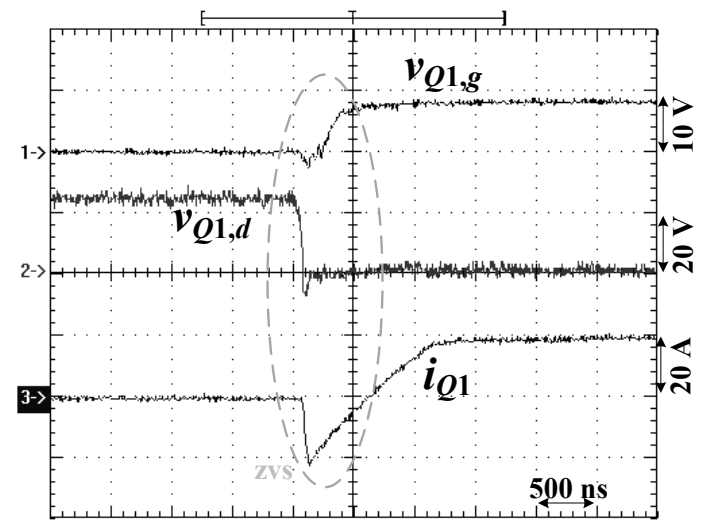

(b)

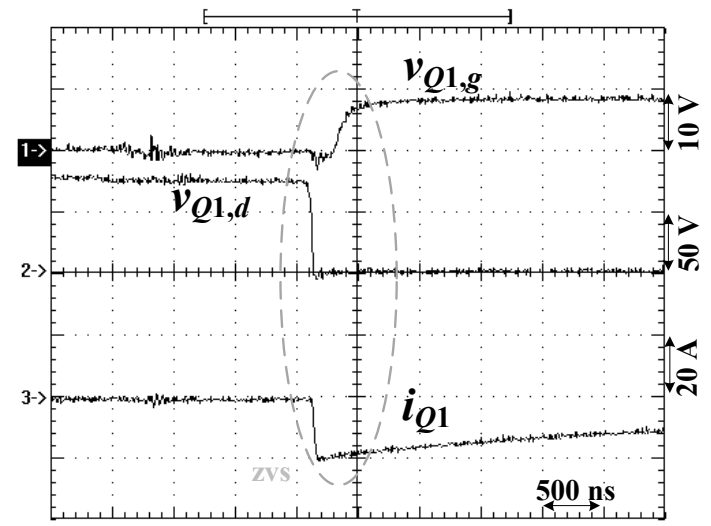

(d)

Figure 8. Experimental waveforms of the leading-leg switch $Q_{1}$ in low input voltage range at (a) $25 \mathrm{~V}$ input and 20\% load (b) $25 \mathrm{~V}$ input and 100\% load (c) $75 \mathrm{~V}$ input and 20\% load (d) $75 \mathrm{~V}$ input and $100 \%$ load.

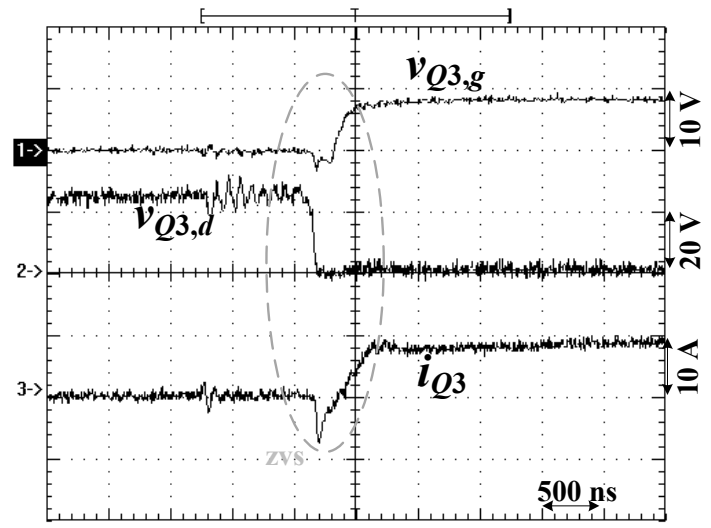

(a)

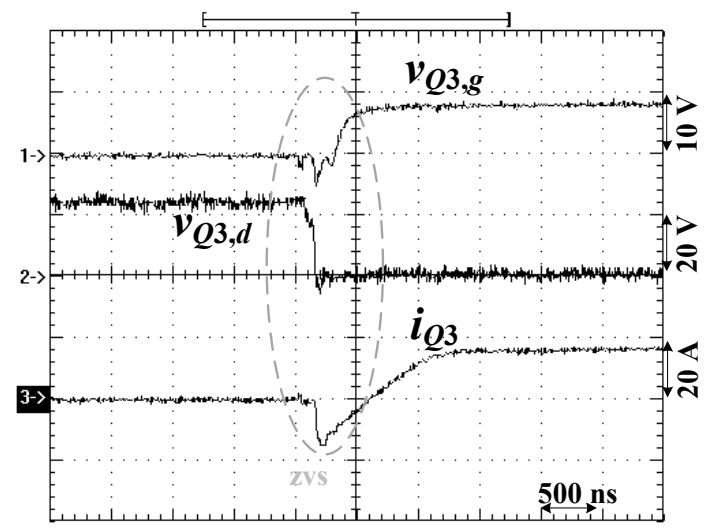

(b)

Figure 9. Cont. 


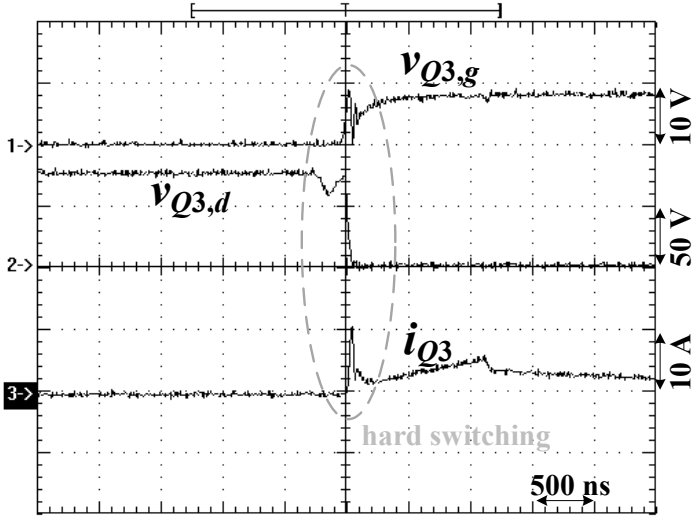

(c)

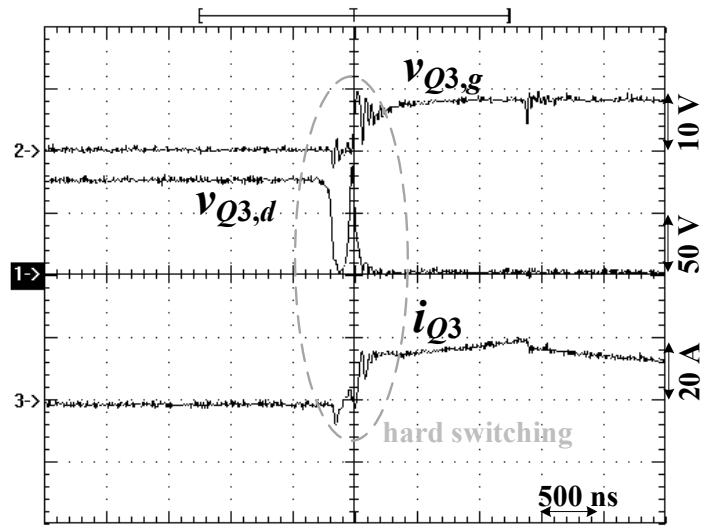

(d)

Figure 9. Experimental waveforms of the lagging-leg switch $Q_{3}$ in low input voltage range at (a) $25 \mathrm{~V}$ input and 20\% load (b) $25 \mathrm{~V}$ input and 100\% load (c) $75 \mathrm{~V}$ input and 20\% load (d) $75 \mathrm{~V}$ input and $100 \%$ load.

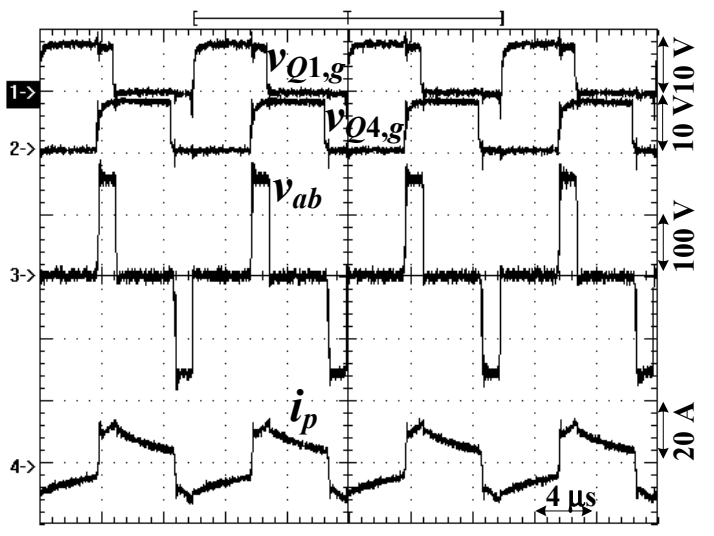

(a)

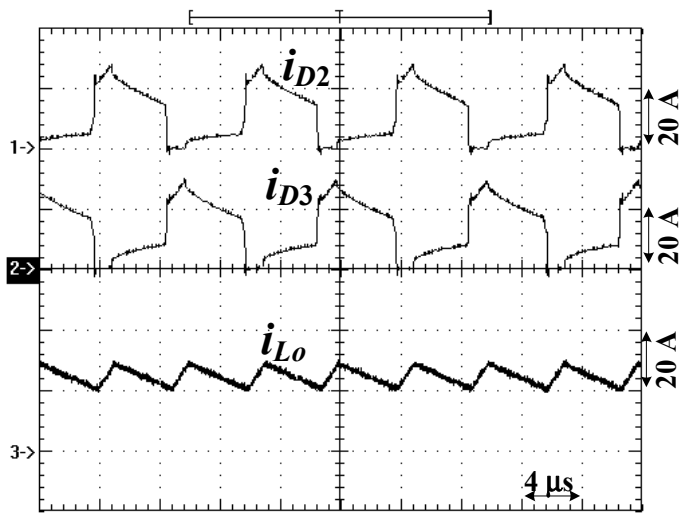

(c)

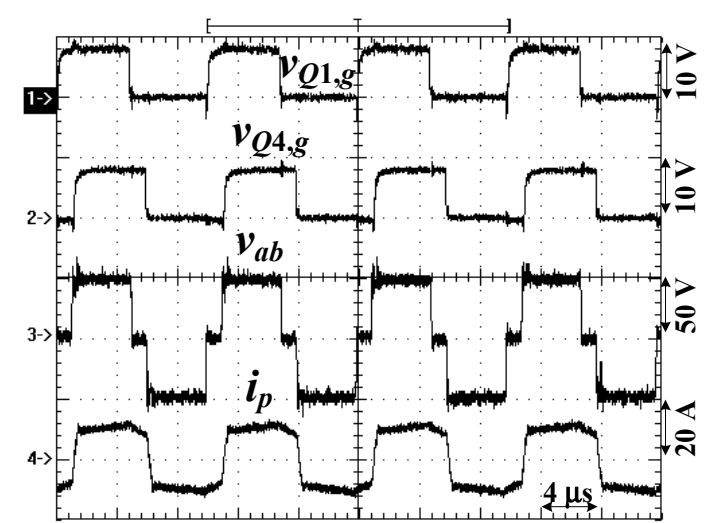

(b)

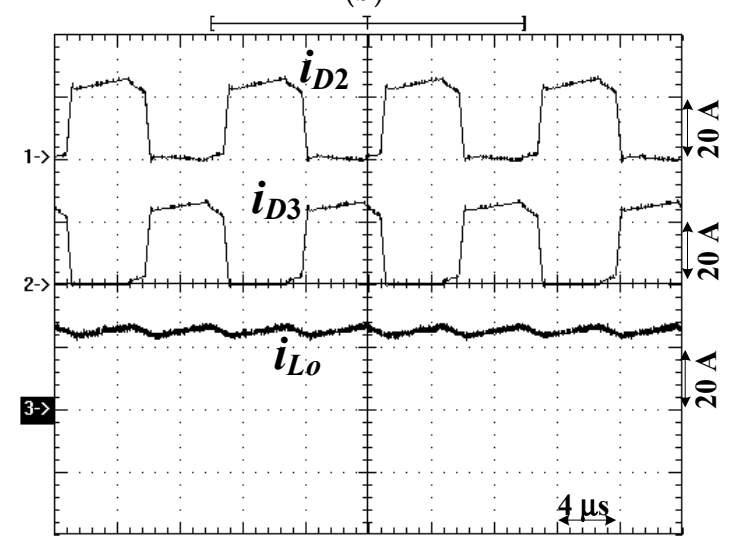

(d)

Figure 10. Experimental results in high input voltage range and full load (a) primary side waveforms at $150 \mathrm{~V}$ input (b) primary side waveforms at $50 \mathrm{~V}$ input (c) secondary side waveforms at $150 \mathrm{~V}$ input (d) secondary side waveforms at $50 \mathrm{~V}$ input. 


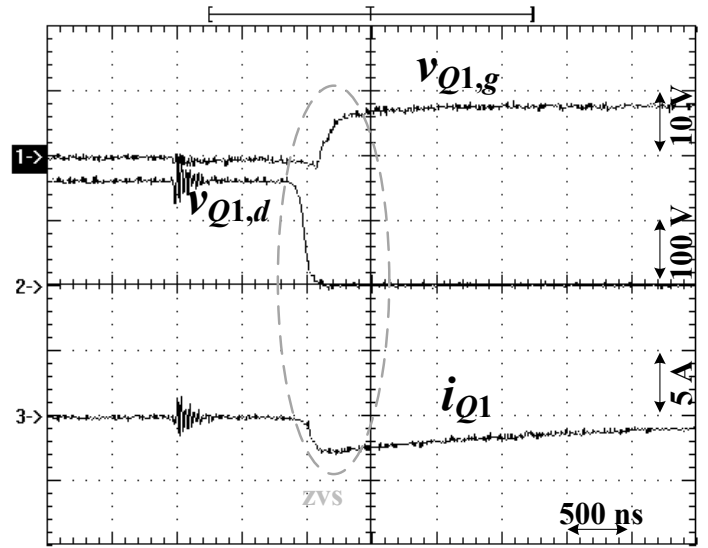

(a)

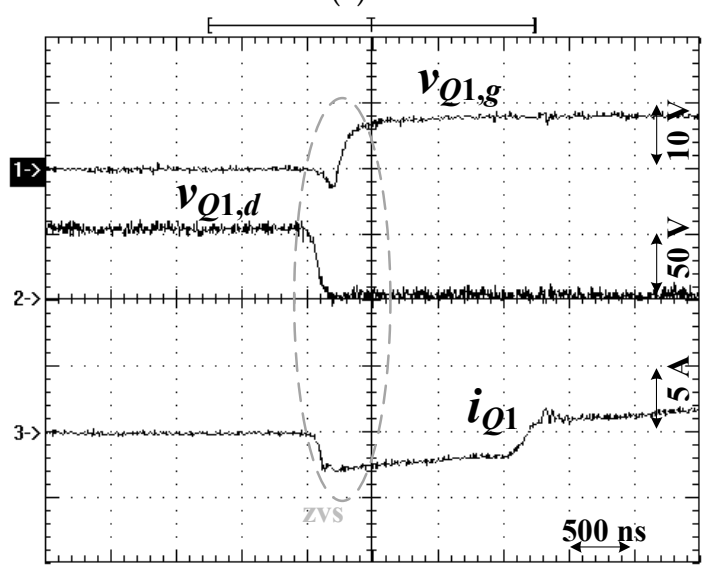

(c)

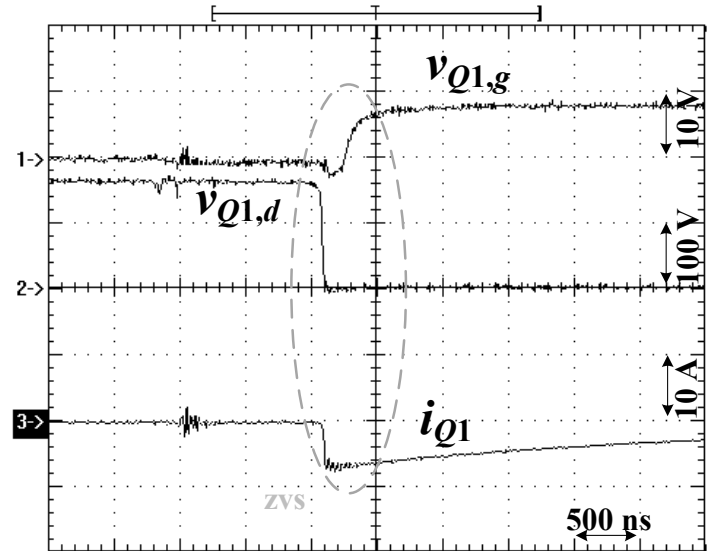

(b)

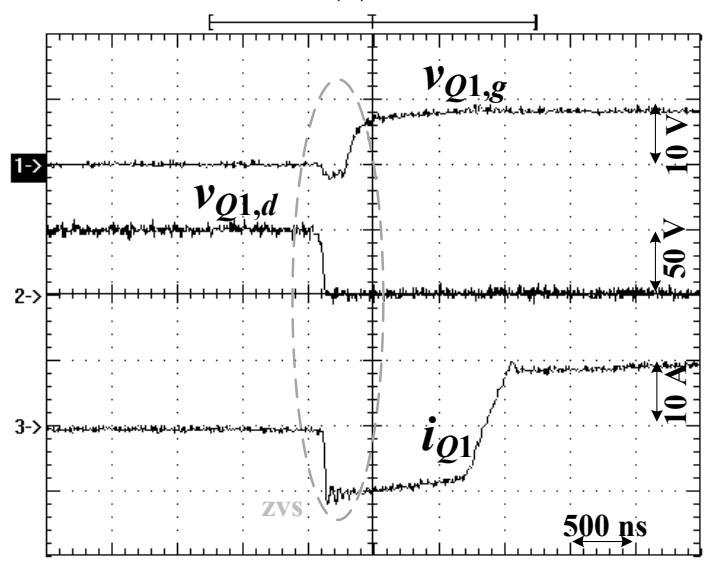

(d)

Figure 11. Experimental waveforms of the leading-leg switch $Q_{1}$ in high input voltage range at (a) $150 \mathrm{~V}$ input and 20\% load (b) $150 \mathrm{~V}$ input and 100\% load (c) $50 \mathrm{~V}$ input and 20\% load (d) $50 \mathrm{~V}$ input and $100 \%$ load.

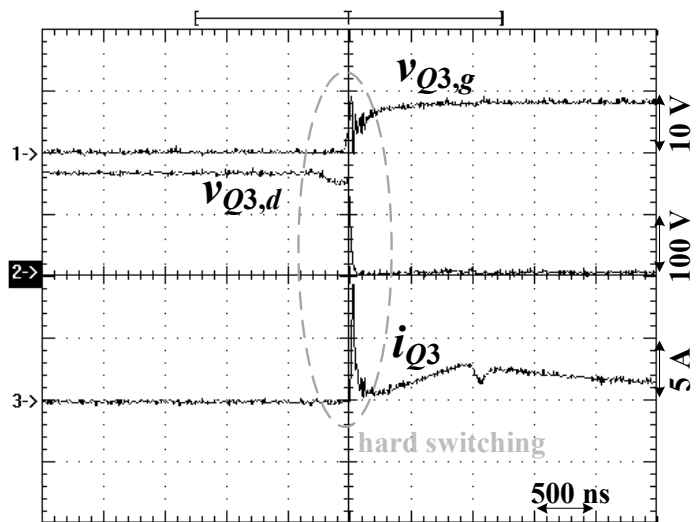

(a)

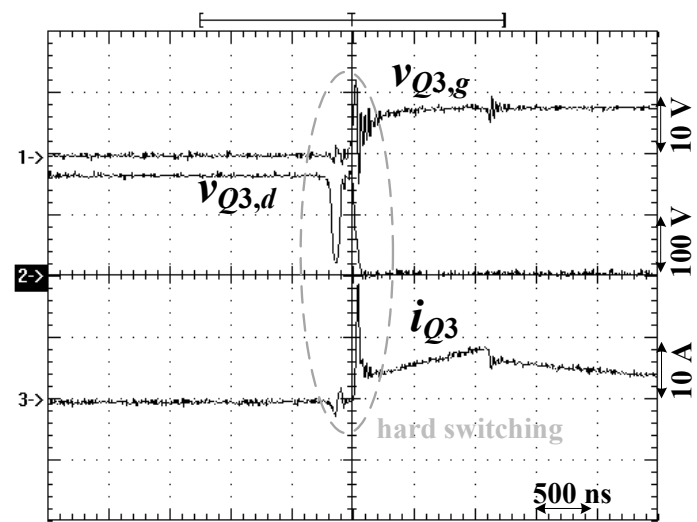

(b)

Figure 12. Cont. 


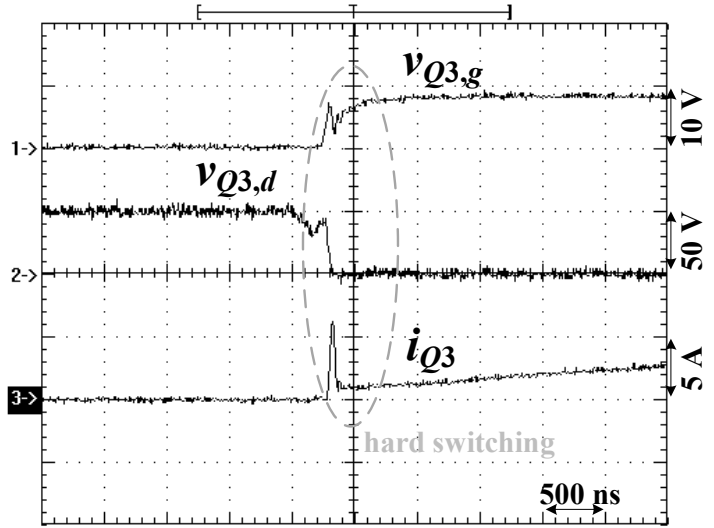

(c)

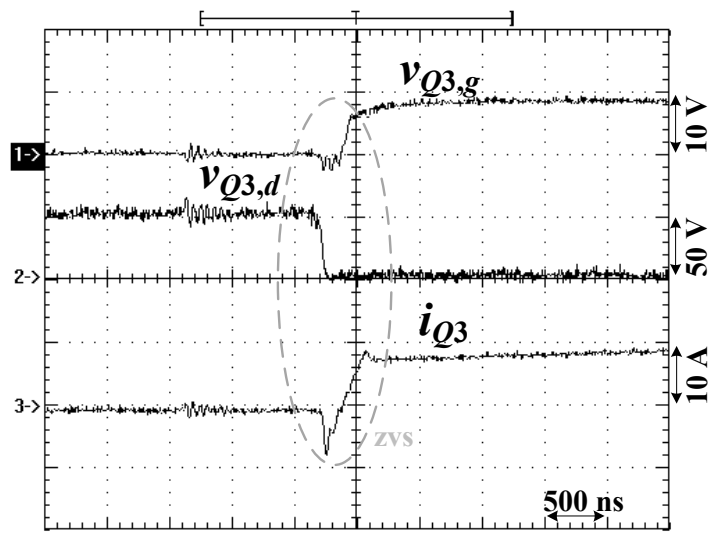

(d)

Figure 12. Experimental waveforms of the lagging-leg switch $Q_{3}$ in high input voltage range at (a) $150 \mathrm{~V}$ input and 20\% load (b) $150 \mathrm{~V}$ input and 100\% load (c) $50 \mathrm{~V}$ input and 20\% load (d) $50 \mathrm{~V}$ input and $100 \%$ load.

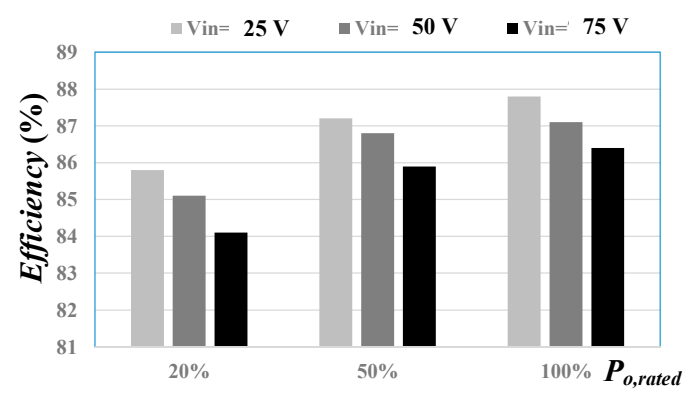

(a)

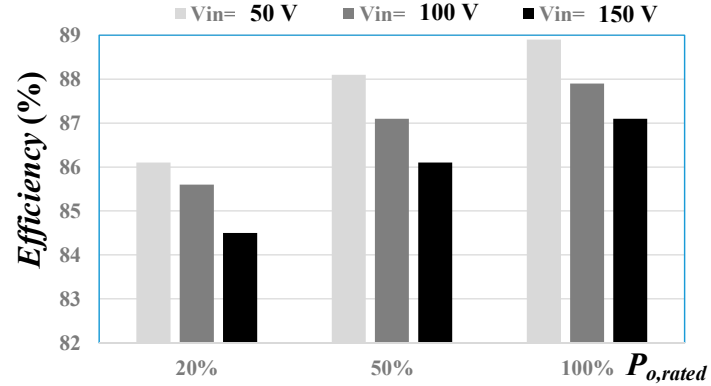

(b)

Figure 13. Measured circuit efficiencies (a) in low input voltage range (b) in high input voltage range.

\section{Conclusions}

A full-bridge PS-PWM converter with auxiliary secondary turns is investigated to demonstrate the capability of 6:1 wide input voltage range operation for railway vehicle low power units and solar power converters. To achieve wide voltage range operation, two sets of secondary windings are used in the studied circuit. According to the different secondary winding turns connected to output terminal, there are two input voltage range operations in the converter. In each voltage range, the circuit can realize the 3:1 input voltage range operation. For low voltage range, the high transformer turns-ratio is adopted to achieve higher dc voltage gain. On the other hand, a low turns-ratio of transformer is used to obtain lower dc voltage gain of the studied circuit. Therefore, a 6:1 wide voltage operation is implemented in the presented converter. PS-PWM scheme is used to accomplish soft switching operation for leading-leg switches. The feasibility of the studied converter is verified and confirmed by a design example and some experiments in this paper.

Funding: This research is funded by the Ministry of Science and Technology, Taiwan, under grant number MOST 108-2221-E-224-022-MY2.

Acknowledgments: This research is supported by the Ministry of Science and Technology, Taiwan, under contract MOST 108-2221-E-224-022-MY2. The author would like to thank H. R. Cheng for his help to measure the circuit waveforms in the experiment. 
Conflicts of Interest: The author declares no potential conflict of interest.

\section{References}

1. Shang, C.; Liu, L.; Liu, M.; Men, S. A highly-efficient two-stage DC-DC converter with wide input voltage. In Proceedings of the 2015 IEEE International Telecommunications Energy Conference (INTELEC), Osaka, Japan, 18-22 October 2015; pp. 1-6.

2. Zhou, G.; Ruan, X.; Wang, X. Input voltage feed-forward control strategy for cascaded DC/DC converters with wide input voltage range. In Proceedings of the 2016 IEEE 8th International Power Electronics and Motion Control Conference (IPEMC-ECCE Asia), Hefei, China, 22-26 May 2016; pp. 603-608.

3. Jeong, Y.; Kim, J.K.; Lee, J.B.; Moon, G.W. An asymmetric half-bridge resonant converter having a reduced conduction loss for DC/DC power applications with a wide range of low input voltage. IEEE Trans. Power Electron. 2017, 32, 7795-7804.

4. Wang, P.; Zhou, L.; Zhang, Y.; Li, J.; Sumner, M. Input-parallel output-series DC-DC boost converter with a wide input voltage range, for fuel cell vehicles. IEEE Trans. Veh. Technol. 2017, 66, 7771-7781. [CrossRef]

5. Zhang, Y.; Fu, C.; Sumner, M.; Wang, P. A wide input-voltage range quasi-Z-source boost DC-DC converter with high-voltage gain for fuel cell vehicles. IEEE Trans. Ind. Electron. 2018, 65, 5201-5212. [CrossRef]

6. Yao, Z.; Xu, J. A three-phase DC-DC converter for low and wide input-voltage range application. In Proceedings of the 2016 the IEEE Transportation Electrification Conference and Expo, Asia-Pacific (ITEC Asia-Pacific), Busan, Korea, 1-4 June 2016; pp. 208-213.

7. Sunddararaj, S.P.; Rangarajan, S.S.; Gopalan, S. Neoteric Fuzzy Control Stratagem and Design of Chopper fed Multilevel Inverter for Enhanced Voltage Output Involving Plug-In Electric Vehicle (PEV) Applications. Electronics 2019, 8, 1092. [CrossRef]

8. Lu, J.; Kumar, A.; Afridi, K.K. Step-down impedance control network resonant DC-DC converter utilizing an enhanced phase-shift control for wide-input-range operation. IEEE Trans. Ind. Appl. 2013, 54, 4523-4536. [CrossRef]

9. Li, W.; Zong, S.; Liu, F.; Yang, H.; He, X.; Wu, B. Secondary-side phase-shift-controlled ZVS DC/DC converter with wide voltage gain for high input voltage applications. IEEE Trans. Power Electron. 2013, 28, 5128-5139. [CrossRef]

10. Wang, X.; Tian, F.; Batarseh, I. High efficiency parallel post regulator for wide range input DC-DC converter. IEEE Trans. Power Electron. 2008, 23, 852-858. [CrossRef]

11. Wu, H.; Wan, C.; Sun, K.; Xing, Y. A high step-down multiple output converter with wide input voltage range based on quasi two-stage architecture and dual-output LLC resonant converter. IEEE Trans. Power Electron. 2015, 30, 1793-1796. [CrossRef]

12. Zong, S.; Fan, G.; Yang, X. Double voltage rectification modulation for bidirectional CLLLC resonant converter for wide voltage range operation. In Proceedings of the 2018 IEEE International Power Electronics and Application Conference and Exposition (PEAC), Shenzhen, China, 4-7 November 2018; pp. 1-6.

13. Cha, H.; Peng, F.Z.; Yoo, D. Z-source resonant DC-DC converter for wide input voltage and load variation. In Proceedings of the 2010 International Power Electronics Conference - ECCE ASIA, Sapporo, Japan, 21-24 June 2010; pp. 995-1000.

14. Kim, B.; Kim, S.; Hun, D.Y.; Choi, J.H.; Kim, M. Hybrid resonant half-bridge DC/DC converter with wide input voltage range. In Proceedings of the 2018 IEEE Applied Power Electronics Conference and Exposition (APEC), San Antonio, TX, USA, 4-8 March 2018; pp. 1876-1881.

15. Lin, B.R.; Lin, G.H. Frequency-Controlled Current-Fed Resonant Converter with No Input Ripple Current. Energies 2018, 11, 1-13.

16. Liu, B.; Jones, E.A.; Wang, F.F.; Zhang, Z.; Costinett, D.; Ren, R. Capacitor-clamped, three-level Gan-based dc-dc converter with dual voltage outputs for battery charger applications. IEEE J. Emerg. Sel. Top. Power Electron. 2016, 4, 841-853.

17. Lin, B.R.; Wu, G.Y. Bidirectional Resonant Converter with Half-Bridge Circuits: Analysis, Design, and Implementation. Energies 2018, 11, 2450. [CrossRef] 
18. Antonio, J.B.; Barbi, I. Input-series and output-series connected modular output capacitor full-bridge PWM DC-DC converter. IEEE Trans. Ind. Electron. 2015, 62, 6213-6221.

19. Lin, B.R.; Lin, G.H.; Jian, A. Resonant converter with voltage-doubler rectifier or full-bridge rectifier for wide-output voltage and high-power applications. Electronics 2019, 8, 3. [CrossRef]

(C) 2020 by the author. Licensee MDPI, Basel, Switzerland. This article is an open access article distributed under the terms and conditions of the Creative Commons Attribution (CC BY) license (http://creativecommons.org/licenses/by/4.0/). 